\title{
Equity, quality and relevance in higher education in Brazil
}

\author{
SIMON SCHWARTZMAN* \\ Instituto de Estudos do Trabalho e Sociedade, 22210-030 Rio de Janeiro, RJ, Brasil \\ Manuscript received on September 9, 2003; accepted for publication on October 28, 2003.
}

\begin{abstract}
Brazilian higher education has doubled its size in the 1990s, going from 1.5 million to more than 3 million students in the period. This expansion was mostly due to the growth of private education, which, in 2002, accounted for about two thirds of the enrollment. Is expansion making higher education more accessible to persons coming from the poorer segments of society? Is the quality of higher education suffering by the speed of this expansion? Is Brazil educating enough qualified persons to attend to the country's needs to participate in the new, knowledge-intensive and global economy? What public policies should be implemented, in order to foster the values of social equity and relevance? What are the policy implications of these developments? This article looks at the available evidence, and suggests some answers to these questions.
\end{abstract}

Key words: higher education, human capital, equity, labor market, education policy.

\section{INTRODUCTION}

Brazilian higher education has doubled its size in the 1990s, going from 1.5 million to more than 3 million students in the period (Figure 1). This expansion was mostly due to the growth of private education, which, in 2002, accounted for about $70 \%$ of the enrollment. Is expansion making higher education more accessible to persons coming from the poorer segments of society? Is the quality of higher education suffering by the speed of this expansion? Is Brazil educating enough qualified persons to attend to the country's needs to participate in the new, knowledge-intensive, global economy? What public policies should be implemented, in order to foster the values of social equity and relevance? What are the policy implications of these developments? This article looks at the available evidence, and suggests some answers to these questions.

*Member of Academia Brasileira de Ciências E-mail: simon@schwartzman.org.br

\section{METHODS}

There are two main sources of statistical information on Brazilian higher education, the Ministry of Education and the Brazilian Institute for Geography and Statistics, IBGE. The Ministry of Education, through the National Institute for Education Research, carries on a yearly census of higher education, through questionnaires filled in by the institutions (INEP 2002). The data from the Ministry of Education is made available on the Internet as consolidated Excel tables, and, for the year 2000, it was possible to obtain micro data at the level of courses and institutions. Through another agency, CAPES, the Ministry collects and organizes information on graduate education (CAPES 2003). The National Institute of Education Research (INEP), also within the Ministry of Education, carries on an assessment of the performance of course programs, the National Assessment of Courses (Exame Nacional de Cursos, known as "Provão"). The mean scores obtained by 


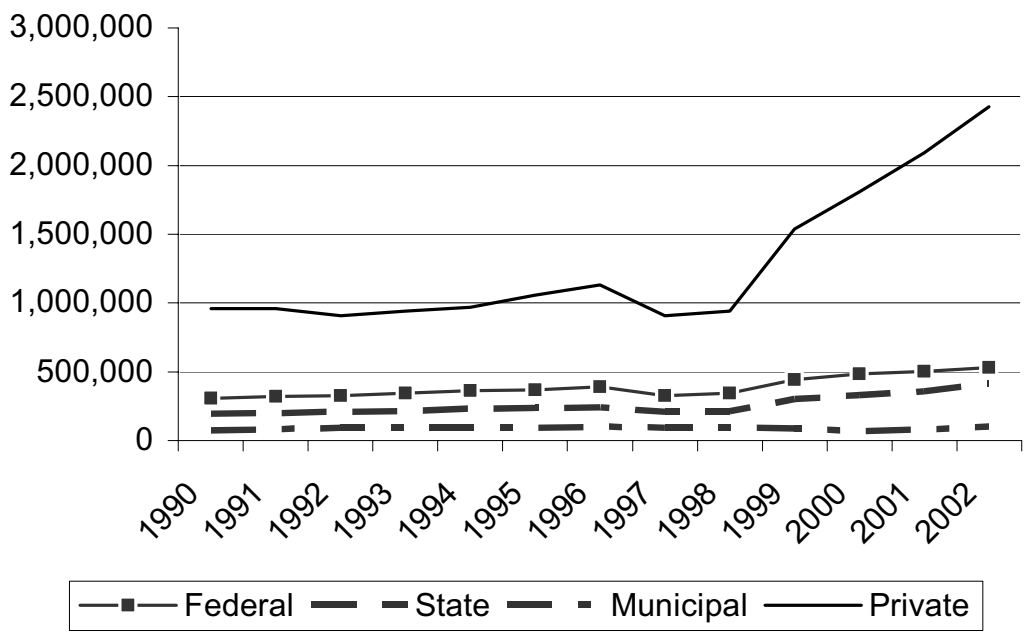

Fig. 1 - Growth of enrollments in higher education, 1990-2002. Sources: INEP. Evolução da Educação Superior - Graduação. Anos: 1980 /1998. Brasília: Ministério da Educação, Instituto Nacional de Estudos e Pesquisas Educacionais 2002; Sinopse Estatística do Ensino Superior - Graduação (1999, 2000, 2001, 2002). Brasília: Ministério da Educação, Instituto Nacional de Estudos e Pesquisas Educacionais. October 2003.

the courses on a five-point scale are available at the course level. The other source of information is the yearly National Household Sample Surveys of the Brazilian Institute for Geography and Statistics, known as PNAD (IBGE 2003). The sample, for 2002 , included about 130,000 households, with information about 385,000 persons, and is representative of the whole Brazilian population, except for the residents in the rural areas of the Northern region. The information is available as micro data, at the level of households and individuals. In this article, we use information from these sources, whether already tabulated by the providers, or processed with commercial statistical software.

\section{RESULTS}

\section{AcCess AND EQuity}

Contrary to widespread assumptions, expansion in the 1990's did not lead to significant changes in the social composition of the Brazilian higher education student body, as shown in Table $\mathrm{I}^{1}$. Tem-year differences are not larger than five percentage points, like in the proportion of students coming from the upper income group, and, notably, the proportion classified as "white". One reason for this stability is that, in spite of recent expansion, higher education in Brazil is still very limited: it reaches only $9.8 \%$ of the population in the 18-24 age group, as compared with much higher levels in many Latin American, European and Asian countries. This is the "net rate" which compares the total number of students in higher education in the age group with the age cohort. The usual figure in international comparisons is the "gross rate", which considers the total number of students regardless of age. For Brazil in

\footnotetext{
${ }^{1}$ This information refers only to students enrolled in regular graduation programs, following secondary education and lasting usually between four and six years, It corresponds to the OECD ISCED-97 5A level, and excludes both students in short-term post-secondary courses (ISCED-97 5B) and ISCED-6, which are the courses leading to advanced degrees (OECD 1999). The use of term "undergraduate" in the American sense to refer to this level is inappropriate, since the Brazilian system is closer to the European model.
} 
TABLE I

Social characteristics of higher education students, 1992 and 2002.

\begin{tabular}{l|r|r}
\hline & \multicolumn{1}{|c|}{1992} & \multicolumn{1}{c}{2002} \\
\hline Women & $53.7 \%$ & $57.8 \%$ \\
Head of households & $17.5 \%$ & $15.8 \%$ \\
Wives or husbands & $11.6 \%$ & $13.2 \%$ \\
Sons & $64.7 \%$ & $63.6 \%$ \\
Other relative in the household & $4.8 \%$ & $6.2 \%$ \\
White & $80.1 \%$ & $75.9 \%$ \\
Mean age & 25.2 & 25.8 \\
Relative household income $(*)$ & 260.3 & 267.1 \\
Percentage coming from the top 10\% household income group & $43.9 \%$ & $41.4 \%$ \\
Percentage coming from the lower 50\% household income group & $8.6 \%$ & $7.5 \%$ \\
Total students & $1,433,206$ & $3,842,488$ \\
\hline
\end{tabular}

(*) for national average $=100$. Source: IBGE 1993 and 2003.

2002, including the students in post-graduate programs, the rate was 16.6. The corresponding numbers for some other countries in the year 2000 were Argentina, 47\%; Chile, 34\%; Korea, 66\%; Portugal, 45\%: Finland, $83 \%$ (Brunner and Elacqua 2003, table 7, p. 32). So, higher education grew by incorporating persons from the same pool of candidates as before, instead of opening up to other social sectors.

Historically, the main explanation for the limited size of Brazilian higher education is the small number of students coming out of secondary education. This segment has been expanding very rapidly in the 1990s. Still, in 2002, only about $40 \%$ of the 15-17 age cohort was in secondary education, while another $38.5 \%$ were lagging behind in primary schools (Schwartzman 2003). Another explanation is that Brazil, differently from most other countries in Latin America, has established numerus clausus for enrollment in public higher education institutions, selecting students through entrance examinations. In some areas, like medicine and journalism, these exams are very competitive, with forty or more applicants per place. In 2001, there were 9.9 applicants per place in federal and 9.4 in state institutions, against 1.7 applicants per place in private institu- tions. In state institutions, there were 59 applicants per place for medical schools, 33 for marketing, 28 for journalism, and 24 for law. In the private sector, there is significant competition only for medicine and dentistry (Table II). Otherwise, to be admitted, it is usually enough to have a secondary school degree and pay the fees. Finally, public expenditures per student in Brazil are the highest in Latin America, at levels similar to that of European countries, because of the large number of full-time faculty enjoying civil-service benefits, and this placed another limitation in the expansion of the provision of public education.

Private higher education started to expand very rapidly in the late sixties, to fill the gap left open by the pubic sector. In 2002, it absorbed $70.5 \%$ of the students. Without public support, the private sector specializes in the social professions - administration, accounting, law, economics and education and most courses are given in the evenings. The assumption, for many years, was that the students in the two sectors were very different, with those in more need having to attend low quality private institutions and pay their fees, while the best educated, coming from richer families, had access to better 
TABLE II

Applicants per place for higher education institutions, 2001.

\begin{tabular}{l|r|r|r|r}
\hline & \multicolumn{4}{|c}{ Ownership } \\
\cline { 2 - 5 } & \multicolumn{1}{|c|}{ State } & Federal & Municipal & Private \\
\hline Engineering and IT & 13.4 & 9.7 & 1.7 & 2.2 \\
Arts, language and humanities & 11.0 & 5.7 & 1.1 & 1.7 \\
Applied social sciences & 16.5 & 12.9 & 3.0 & 2.7 \\
Natural sciences & 10.1 & 7.6 & 1.4 & 2.0 \\
Social sciences & 9.0 & 8.0 & 0.5 & 1.7 \\
Education & 6.8 & 6.6 & 1.6 & 1.5 \\
Health, pharmacy & 21.0 & 15.9 & 3.2 & 2.8 \\
Medicine and dentistry & 42.4 & 32.2 & 19.1 & 12.4 \\
Agricultural activities & 11.8 & 8.8 & 1.2 & 2.2 \\
Total applicants & 951,594 & $1,129,749$ & 59,044 & $1,685,906$ \\
Total openings & 96,179 & 120,486 & 28,967 & 970,655 \\
\hline
\end{tabular}

Source: Tabulated from the 2001 Higher Education Census, Ministério da Educação.

and free universities.

Information on private and public enrollments (available only since PNAD 2001), however, shows a more complex picture. In $2002,48 \%$ of the students in private institutions belonged to the $10 \%$ richer segment of the population, with mean family income of 5,525 reais $^{2}$ a month, while, in the public sector, only $34.2 \%$ of the students reached this level. At the other extreme, $13.7 \%$ of the students in the public sector came from families from the bottom half of the income ladder, as compared with $5.6 \%$ of those in private institutions (Figure 2). $75 \%$ of the students in the private sector defined themselves as "white" in the PNAD survey, as against $62 \%$ in the public one. The other main difference is that, in the public sector, $33 \%$ of the students do not work, compared with $21 \%$ in the private side. However, there is no age difference between the groups - a little above 26 on average for both. Overall, the social composition of students in the public sector is slightly less skewed than that of the private sector, with a larger percentage of poorer and non-white students, and a smaller percentage of the richer ones. This com-

\footnotetext{
2 The exchange rate in September 2002, when the survey was taken, was about 3 reais per US dollar.
}

bination of higher income and more work among students in private institutions, against less income and less work among those in the public sector, for populations of similar age, suggest important sociological differences these two groups of students, still to be explored.

The higher quality of many course programs in the public sector, expressed both by their selectivity and their marks in the National Assessment of Courses (see below), suggest the hypothesis that, even if richer students are going to private education, students coming from the best educated families are still going to public institutions. To test this hypothesis, a measure of the student's " cultural capital" was developed, calculating the mean number of years of education of their family members with 18 years and more. However, Table III shows that, as a whole, the "cultural capital" of students in the public and private sectors is rigorously the same.

In recent years, public institutions have been under pressure to expand and be more open to students coming from lower socioeconomic backgrounds. The National Education Plan, approved by Congress in 2000, established that $30 \%$ or the $18-24-$ age cohort should be enrolled in higher education by 

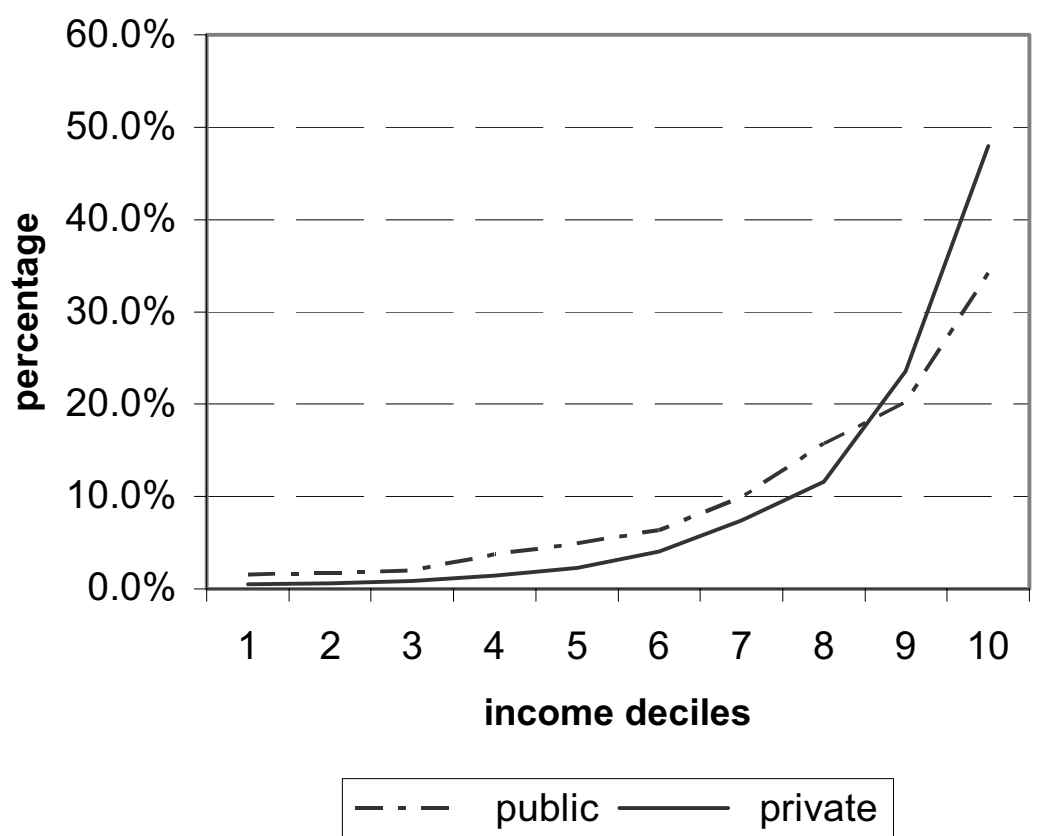

Fig. 2 - Higher education students: public/private enrollment and family income, 2002. Source: IBGE 2003.

2010, forty percent of which in public institutions. This proportion was vetoed by President Fernando Henrique Cardoso in 2001, but under strong criticism from the opposition, which won the election in the following year (Presidência da República 2001). Several universities are experimenting with different types of quota systems and affirmative action. Thus, the state universities in Rio de Janeiro and Bahia have introduced quotas for non-whites and students coming from public secondary schools (Governo do Estado do Rio de Janeiro 2000, Universidade do Estado da Bahia 2002), and the Federal universities are being urged to expand enrollment and provide more evening courses. Racial quotas for higher education is a controversial policy (Fry 2000, Telles 2003), but affirmative action on behalf of students from poorer backgrounds is less so. A coherent policy of this kind, to be successful, would require special efforts to provide appropriate study programs to compensate for these students' inadequate secondary education, and additional resources to implement them. So far, however, there are not examples of such ef- forts, and a populist policy of expansion could reduce the quality of the public sector and stimulate the growth of elite private higher education. In this scenario, public higher education would become more equitable, not by its virtues, but by its shortcomings.

\section{QUALITY AND DIFFERENTIATION}

Higher education in Brazil is very heterogeneous, both in the public and private sectors. The legislation distinguishes between universities, university centers, integrated, and isolated faculties of schools. They have different levels of autonomy, but the degrees they provide are legally equivalent. The expectation, written in the Constitution, is that all universities should link research with teaching and extension work, but this is the exception, rather than the rule, even among public universities.

In the public sector, there is a network of 67 Federal institutions, most of them universities, working under a unified pay scale, but with large differences in quality. Besides, there is a growing network of state-owned institutions, and a few mu- 
TABLE III

Enrollment in public and private higher education, by the family's "education climate", 2002.

\begin{tabular}{l|c|r|r}
\hline $\begin{array}{c}\text { "Education climate" } \\
\text { quintiles }\end{array}$ & $\begin{array}{c}\text { Mean years of schooling } \\
\left.\text { of other family members }{ }^{*}\right)\end{array}$ & Public & Private \\
\hline 1 & 2.3 & 2.8 & 1.7 \\
2 & 5.1 & 5.1 & 6.1 \\
3 & 7.5 & 12.1 & 11.2 \\
4 & 10.3 & 23.1 & 23.1 \\
\multicolumn{1}{c|}{} & 13.7 & 57.0 & 58.0 \\
\hline total & & $100.0 \%$ & $100.0 \%$ \\
mean & & 11.4 & 11.5 \\
st deviation & & 3.3 & 3.2 \\
Total number of students & & 985,849 & $2,729,532$ \\
\hline
\end{tabular}

(*) excludes students living alone. Source: IBGE 2003.

nicipal ones. The state universities of São Paulo provide most of Brazil's doctoral degrees, and tend to be research intensive in many areas; in other state institutions, there are few or no advanced degree programs, and very little research. In the private sector, there are several very large and many very small institutions, teaching one or two evening courses in the social professions. Some of the largest private institutions are universities, but they lack significant graduate degree programs, and do very little research (Schwartzman and Schwartzman 2002).

The best information available on the quality of Brazilian higher education is the National Assessment of Courses, a test required to all students graduating in most fields. This exam was established by the Ministry of Education under President Fernando Henrique Cardoso. Under President Luis Inácio da Silva, a Committee was established to revise the whole higher education quality assessment system in the country, and it suggested that the $\mathrm{Na}-$ tional Assessment of Courses should be abolished on its present form (Comissão Especial da Avaliação da Educação Superior 2003). At this writing (October 2003), the issue is still under discussion.

Individual scores in the National Exam are kept confidential, but the average results of each course program are used to rank them along a scale from " $A$ " to " $\mathrm{E}$ ", according to their statistical distribution within each field. In 2001, there were 12,155 course programs in Brazilian institutions; in 2002, 5,016 of them went through this procedure, in a selected number of fields. Together with this exam, the students are asked to respond to a socioeconomic questionnaire, which could be used to better understand their characteristics. This information, however, is not in public domain.

With this instrument, it is not possible to compare the quality of different fields, since, by definition, the mean score in each field is always " $\mathrm{C}$ '. We can, however, calculate means and compare types of institutions and regions, converting the concepts of the " $A$ " to " $C$ " scale into a scale from 1 to 5 (Table IV).

Figures 3 and 4 show the large variations in quality that occur within each region and type of institution. On average, the best segment is the federal system, particularly in the southeastern region. The average score of the federal universities in the Federal District (Brasilia) is 1.4, and, in the State of Minas Gerais, 1.6. Variations due to institutional differences are larger than those due to regional differences: the range, for the first, is 1.8 , while for the 
TABLE IV

National Course Exam, mean scores of course programs, 2002.

\begin{tabular}{l|r|r|r|r|r|c}
\hline \multirow{2}{*}{ Region } & \multicolumn{4}{|c|}{ Type of institution } & Total & Number of \\
\cline { 2 - 5 } & State & Federal & Municipal & Private & & course programs \\
\hline North & 4.0 & 3.1 & 4.3 & 3.6 & 3.4 & 262 \\
Northeast & 3.4 & 2.7 & 3.9 & 3.4 & 3.2 & 882 \\
Southeast & 2.2 & 1.8 & 3.3 & 3.2 & 3.0 & 2,360 \\
South & 2.4 & 2.0 & 3.0 & 3.0 & 2.8 & 1,065 \\
Center West & 3.5 & 2.4 & 4.1 & 3.5 & 3.2 & 489 \\
\hline Total & 3.0 & 2.4 & 3.5 & 3.2 & 3.0 & 5,058 \\
Number of course programs & 882 & 884 & 166 & 3,126 & 5,058 & \\
\hline
\end{tabular}

Source: tabulated from the National Course Exam data set, provided by the Ministério da Educação.

second it is 0.7 . This observation is confirmed by analysis of variance (in both cases, between group differences are significant at .000 levels, with an " $E$ ta" coefficient of association of .263 for institutions, and .157 for regions).

\section{ReLEVANCE}

How important is education for society? The prevailing opinion among experts and laymen is that, the more education, the better. In economics, there is a vast literature demonstrating the importance of human capital for economic development and the reduction of income inequality (Becker 1964, Schultz 1994), and a renewed concern for the need of advanced competencies to face the knowledge requirements of the new economy (Brunner and Elacqua 2003, De Ferranti et al. 2003). However, there is also a more skeptical view, particularly regarding the social benefits of uncontrolled expansion of higher education (Collins 1979, 2000, Schwartzman 2002a, Wolf 2002). In the past, it was believed that it would be possible to plan the growth of higher education according to a country's needs, based on some technical estimation of manpower requirements. More recently, this approach was abandoned, due to the rapid changes in the technology and the peculiar variations in the organization of the professions, and replaced by a more general concern with the development of broad competencies and skills (Fulton et al. 1982, Serageldin and Li 1983, Stern et al. 2000).

The individual, private benefits of higher education are well documented. Figure 5 shows the distribution of monthly income according to years of education for persons between 25 and 40 years of age, in 2002. Incomes of persons with 15 years of more of schooling - that is, higher education - are about three times the income of those with 11 years of schooling - secondary education. Economists measure the "rates of return" of investments in education, and find that, in Latin America, the private returns of higher education are consistently very high (Leal and Werlang 1990, Psacharopoulos and Patrinos 2002, Ueda and Hoffmann 2002). There are also attempts to measure the social benefits of education, but these results are more difficult to interpret and more subject to controversy.

In the past, the assumption was that, for each learned profession, a corresponding university level course should exist. This image persists in Brazil, with the additional complication that there are several dozen professions regulated by law, each with their specific education requirements and market prerogatives. In practice, however, these regulations work only for a few fields, such as medicine, engineering and law, and most higher education today tends to be general, rather than specialized (Castro and Levy 2000). In Brazil, as Table V shows, most students are in the applied social sciences fields 


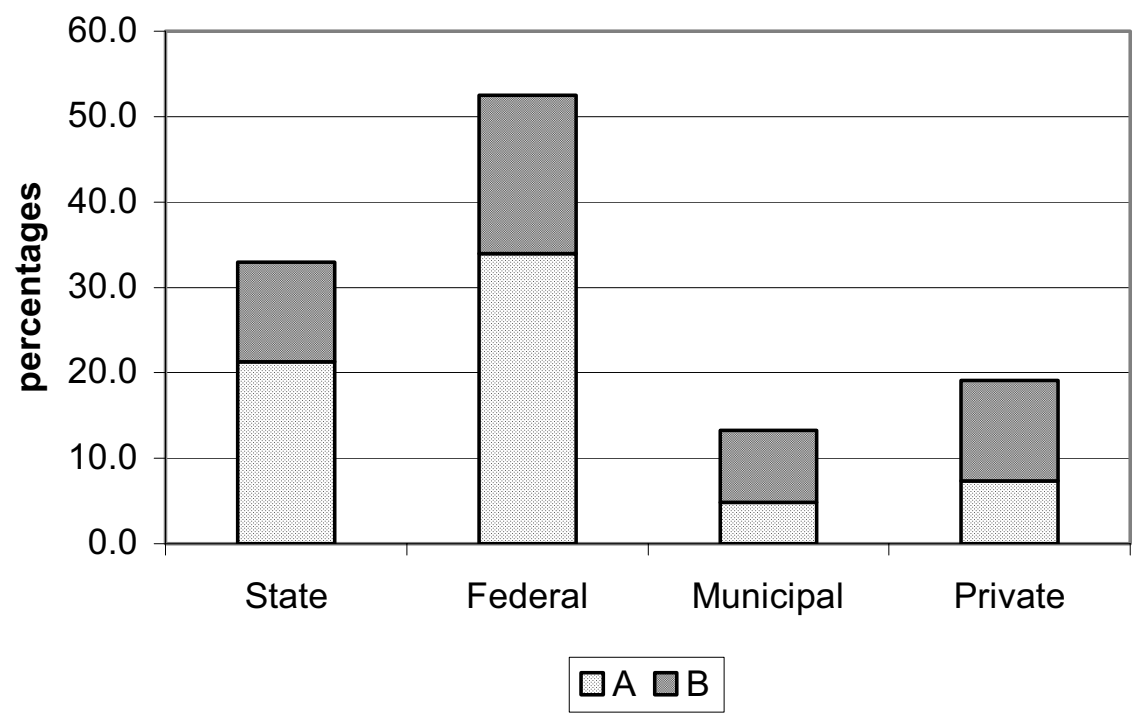

Fig. 3 - Percentage of A and B courses, by type of institution. Source: tabulated from the National Course Exam data set, provided by the Ministério da Educação.

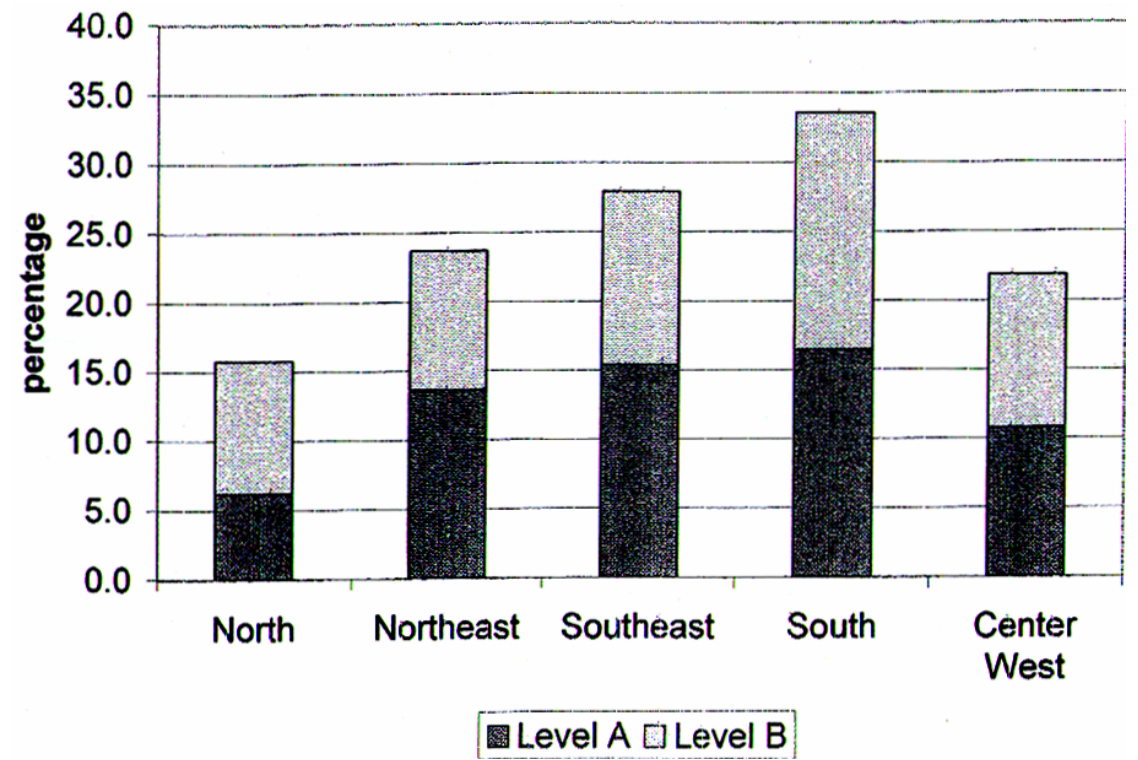

Fig. 4 - Percentage of A and B courses, by region. Source: tabulated from the National Course Exam data set, provided by the Ministério da Educação.

(including administration, economics, and similar subjects) where, except for law and accounting, the labor market is largely not organized along the established professions. The second largest group is education, which is a consequence of the legal requirement that all teachers in elementary education, which until recently had only a secondary school degree, should have a higher education title. Ele- 


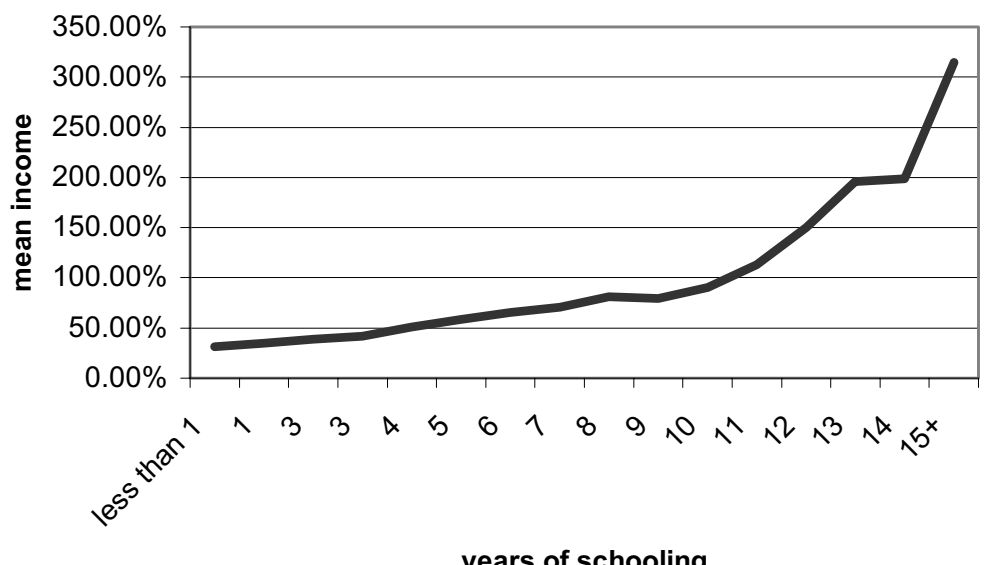

Fig. 5 - Mean income, by years of schooling (reais, October 2002). Source: IBGE 2003.

TABLE V

Enrollments in higher education by type of institution and field.

\begin{tabular}{|c|c|c|c|c|c|c|c|}
\hline & \multicolumn{6}{|c|}{ Percentages } & \multirow[t]{2}{*}{ Total } \\
\hline & Federal & State & Municipal & $\begin{array}{l}\text { Private } \\
\text { for profit }\end{array}$ & $\begin{array}{c}\text { Private } \\
\text { non-profit }\end{array}$ & Total & \\
\hline Engineering, IT & 20.8 & 15.4 & 16.7 & 15.9 & 18.9 & 17.8 & 478,247 \\
\hline Arts, language and humanities & 4.8 & 3.4 & 1.5 & 1.4 & 1.2 & 2.2 & 59,163 \\
\hline applied social sciences, law & 22.4 & 19.0 & 42.1 & 52.1 & 45.1 & 40.0 & $1,078,385$ \\
\hline biological and physical sciences & 7.8 & 4.3 & 0.9 & 1.6 & 1.9 & 3.2 & 85,020 \\
\hline social sciences & 4.6 & 2.3 & 0.1 & 0.4 & 1.0 & 1.6 & 43,074 \\
\hline education & 20.6 & 43.3 & 30.7 & 17.0 & 18.3 & 21.7 & 584,664 \\
\hline health and caring & 6.7 & 4.9 & 4.1 & 7.7 & 8.5 & 7.4 & 198,543 \\
\hline medicine and dentistry & 6.5 & 3.7 & 2.6 & 2.4 & 3.8 & 3.8 & 101,810 \\
\hline agriculture, natural products & 5.8 & 3.8 & 1.4 & 1.4 & 1.2 & 2.4 & 65,339 \\
\hline & 100 & 100 & 100 & 100 & 100 & 100 & \\
\hline Total & 482,750 & 332,104 & 72,172 & 880,555 & 926,664 & & $2,694,245$ \\
\hline
\end{tabular}

Source: tabulated from the 2000 higher education census, Ministério da Educação.

mentary and secondary education are the responsibility of states and municipalities, and this explains why most state and municipal institutions emphasize this field. Half the enrollment in the private sector, both in the for-profit and non-profit institutions (including the religious and community-based institutions), are in the applied social sciences. The pattern for federal universities is not very different, except that there is relatively more emphasis on en- gineering, the sciences, medicine, and agriculture.

There are three possible explanations for this strong emphasis on the applied social sciences, or social professions. One would be that these are the cheapest course programs, not requiring investments in equipment and highly qualified personnel; the second is that most students applying to higher education do not have the necessary qualifications to enter more exacting fields; the third is that these 
fields are more demanded by the labor market. The first two explanations are more likely to be true, and the question is whether the third is also valid.

Table VI helps to answer this question. Most jobs for persons with higher education are in services and the social professions (education, personal services, health care, administration, commerce). In the decade, the number of jobs for persons with higher education increased by $24 \%$, reflecting the slow growth of higher education in the previous decade, and most of this increase also took place in the service and social professions. This could be interpreted as meaning that this is where the demand for higher education is stronger; however, the largest group, of "social activities and education", is also the segment with the lowest revenues. The proper interpretation, therefore, is that the job market is not creating well-qualified and well-paid job opportunities, and the social professions are the main alternative for the growing number of persons obtaining their higher education degrees.

Table VII makes use of a new classification of occupations introduced in the 2002 National Household Survey, and compares the occupation profiles of three generations of persons with higher education degrees. The differences may be a function of evolving career paths, related to seniority, and also to the changing work opportunities for each new generation. Thus, about one fourth of the older generation occupy top managerial positions, and income is strongly related to age. In the younger generation, about $25 \%$ are in mid-level technical and administrative positions, which may not require higher education qualifications. It is possible that, on time, these persons would move to more qualified positions; but, if the number of graduates increase, and the job market is not changing fast enough, the new generation may not have the chance to become like the old one. Almost half of the graduates work as professionals in sciences and arts, and this figures is stable among generations, suggesting that the "proletarization" of the educated, which is often presented as a matter of fact, actually is not taking happening. A better understanding of the current and future trends would require a much more detailed analysis of the effective contents of occupations and professions and their change through time (like the work reported in Elias and Purcell 2003), which Brazil still lacks.

A society with better educated teachers, administrators, traders, health care and personal service providers should be a better place to live than a society without them. A country needs teachers to provide better education to children, and this is an important asset. At the same time, there is no evidence that the expansion of higher education in Brazil is having a direct impact on economic development. This is not surprising. On the short run, economic growth has more to do with macroeconomic variables than with the availability of human capital. (Sáinz and La Fuente 2001). On the long run, it seems clear that no sustained and wellbalanced economic development can happen without an important pool of competent and well educated professionals. However, there is a growing literature arguing that the expansion of higher education worldwide is more related to life styles and competition for scarce jobs than to functional requirements of the job markets (Wolf 2002). In the absence of demands for skills, continuous expansion of higher education may reinforce the tendency to make credentials more important than professional competence. This tendency can be costly to society, and thwart the ability of higher education institutions to develop the abilities and skills that could help to break the vicious circle of low economic development and the shortage well-qualified human capital.

\section{Post-Graduate Education}

If the tendency is for knowledge-intensive occupations to concentrate in a few places and institutions, is Brazil producing enough well-qualified, high-level personnel, to respond to this qualified demand? 
TABLE VI

Occupations of persons with higher education, 1992-2001.

\begin{tabular}{l|r|r|r|r}
\hline Occupations & \multicolumn{1}{|c|}{1992} & \multicolumn{1}{c|}{2001} & $\begin{array}{c}\text { change } \\
1992-2001\end{array}$ & $\begin{array}{c}\text { mean monthly } \\
\text { income, 2001(*) }\end{array}$ \\
\hline Agriculture & $2.0 \%$ & $1.4 \%$ & $-0.6 \%$ & $2,034.45$ \\
Industry & $12.1 \%$ & $9.2 \%$ & $-2.9 \%$ & $2,525.28$ \\
Construction & $2.2 \%$ & $1.6 \%$ & $-0.6 \%$ & $2,586.38$ \\
Other industrial activities & $2.0 \%$ & $1.3 \%$ & $-0.8 \%$ & $2,326.33$ \\
Commerce & $9.5 \%$ & $11.2 \%$ & $1.6 \%$ & $1,812.59$ \\
Services to business & $4.0 \%$ & $6.1 \%$ & $2.1 \%$ & $1,380.19$ \\
Public administration & $10.4 \%$ & $14.2 \%$ & $3.8 \%$ & $2,369.89$ \\
Transportation and communications & $2.6 \%$ & $2.7 \%$ & $0.2 \%$ & $2,178.56$ \\
Social activities, education & $33.8 \%$ & $34.3 \%$ & $0.5 \%$ & $1,637.14$ \\
Public administration & $13.1 \%$ & $12.2 \%$ & $-0.9 \%$ & $2,324.58$ \\
others & $8.2 \%$ & $5.8 \%$ & $-2.4 \%$ & $2,266.40$ \\
Total econ. active & $5,142,229$ & $6,396,257$ & $24 \%$ & $1,989.96$ \\
\hline
\end{tabular}

(*) income from all kinds of work, reais of September 2001. Source: IBGE 1993 and 2002.

\section{TABLE VII}

Brazil, occupation of persons with higher education(*), by age groups, 2002.

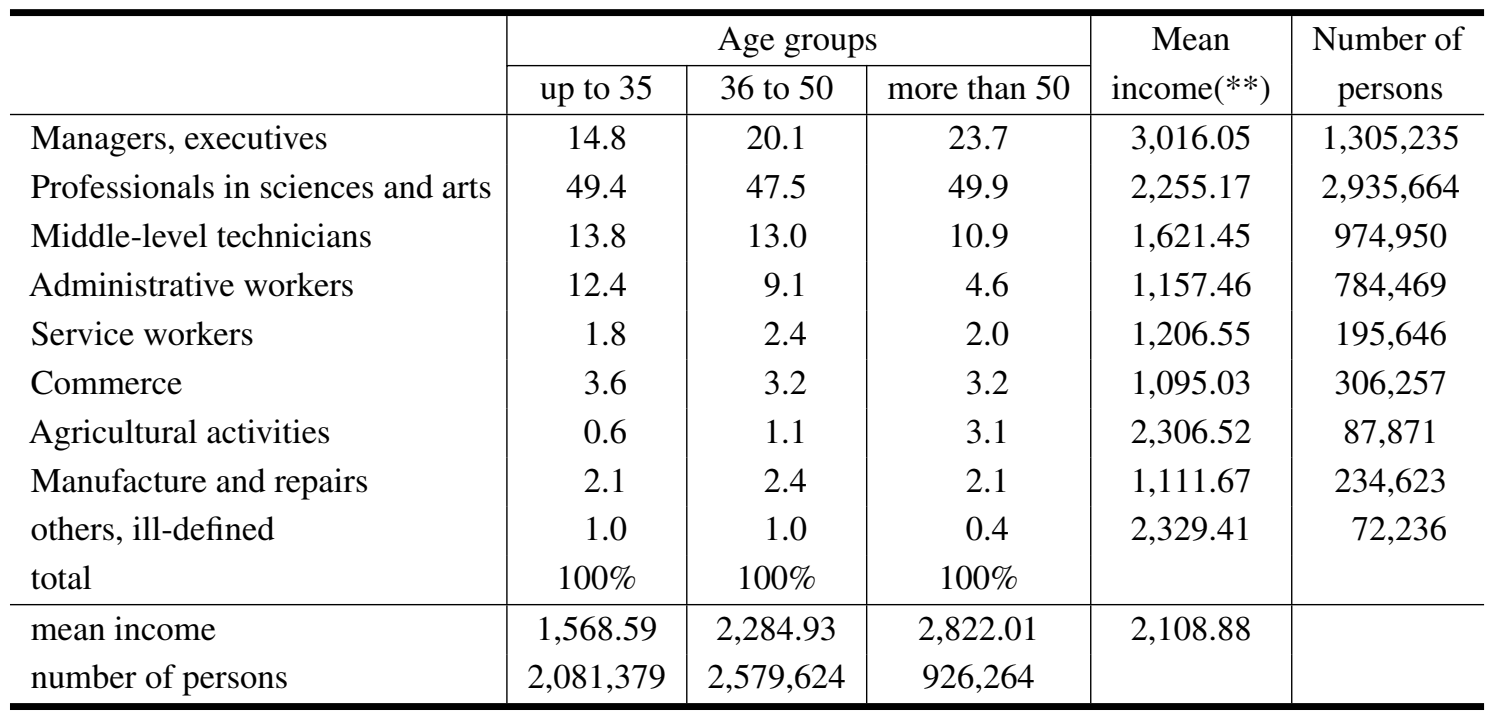

(*) graduate and post-graduate. (**) income from all kinds of work, reais of September 2002. Source: IBGE 2003. 
Post-graduate education is supported by the Ministry of Education, $u$ the Ministry of Science and Technology and state institutions such as São Paulo's Fundação de Amparo à Pequisa (FAPESP), under the assumption that this is the best way to form the high-level manpower needed to support Brazil's science and technology. Thanks to this combined effort, Brazil has the largest post-graduate education establishment in Latin America. In 2001, six thousand students received their doctoral degrees and 30 thousand their Masters'. This segment is heavily subsidized. Most courses are in public institutions, students do not have to pay tuition, and there are many opportunities for fellowships, particularly for doctoral students. According to one estimate, in 1999, public support for the post-graduate system consumed about $54 \%$ of the country's public investments in Research and Development (Ministério de Ciência e Tecnologia 1999, Balbachevsky 2004).

These figures refer only to degree programs, excluding the vast and unknown segment of nondegree programs, of which the new MBAs are a significant and growing portion. Follow-up studies done on the professional careers of professional degree-holders show that most holders of master's degrees work outside academia, such as in firms (mostly private), in public administration or as liberal professionals. Among Ph.D. holders, more than $60 \%$ work in academic institutions, either in public universities or in public research institutions. The proportion of academic employment is not significantly diverse among doctors, whether in hard or soft sciences, or in fields professionally or academically oriented. While $90 \%$ of all doctors in Physics and Biochemistry are in the academia, 86 per cent of those in Electrical Engineering hold faculty positions or work at research institutes. While $60 \%$ of chemists and sociologists find employment in the academic marketplace, about three fourths of economists, civil and mechanical engineers, and psychologists, have the same kind of jobs (Velloso and Balbachevsky 2002, Balbachevsky 2004). The heavy concentration of doctor degree holders in academic work is related to the fact that most scientific and technological research in Brazil takes place in universities, with less links with industry and public policy agencies than could be expected (Schwartzman 2002b).

The expansion of post-graduate education is having a clear impact on the growing number of degree holders in the staff of higher education institutions, a legal requirement. Its impact in the economy is less clear. For specialists in administration, engineering and in the medical profession, to have a master degree is a competitive advantage in the professional market. Ph.D. holders, on the other hand, may be too qualified for non-academic work, or may prefer to remain in the academic university. More information is needed to ascertain the effective impact of post-graduate education in the improvement of Brazil's social and economic conditions. From what we know, however, the strong impression is that the private benefits of post-graduate education are much more tangible than the social ones.

\section{DISCUSSION AND POLICY IMPLICATIONS}

Higher education is expanding in Brazil as a consequence of the universal trend for young generations to extend their student life, and the improved income opportunities for those with better education credentials. There are several assumptions and common beliefs about this expansion which are not confirmed by the existing data and specialized literature, and a revision of these assumptions can lead to significant changes in higher education policies.

The conventional view can be summarized as follows. Higher education is an important social good, because of the benefits it brings to the development of the economy and society. The expansion of recent years is broadening its social basis, bringing in students from lower social backgrounds. Because of this expansion, quality is suffering. Public institutions have been able to preserve quality, because they are selective, and are not driven by profit considerations. Private institutions, on the contrary, cater to students who cannot pass the entrance ex- 
aminations to the public sector, and can only study in the evening. For these institutions, profits, not education, is the main concern. The main policy implications that follow from this view is that society should expand and subsidize higher education, but only in the public sector, where quality is preserved; and government should keep the private sector under close control and supervision, to minimize its shortcomings. On the long run, resources allowing, all higher education should be free and public, and organized along the Humdoldt ideals of integration among research, teaching and extension, as written in the Brazilian Constitution.

In our analysis, we find no evidence that the growth of higher education is a response to the demands of a changing labor market. Brazilian higher education doubled its size in the 1990's, when the economy was largely stagnant. Perhaps because of the limitations of the available data, we do not see any clear trend in transforming the country's growing human capital (measured in years of schooling) into tangible social or economic benefits. Another finding is that the expansion of the last decade did not mean that the social basis of higher education is broadening.

Regarding the differences between the public and private sectors, we find that, although the public sector tends to have a higher proportion of good quality course programs, the similarities between the two sectors are large. Both have good and bad quality courses and institutions, and the social profile of the students are very similar, with a possible trend of the private sector to absorb more students from the upper income segments.

The main policy issues associated with this analysis are those of public subsidies, improvement of quality and competence, and equity. Higher education, in all countries, is subsidized to a certain degree, and it is difficult to establish how far this public subsidy should go. In most countries outside Western Europe, which has a tradition of mostly public and fully subsidized higher education, students are asked to pay for their education, whether in public or in private institutions. The distinction between "public" and "private" is less clear than it seems. In Brazil, public means "state-owned", while private includes for-profit, non-profit, charity, religious, community-based and other types of institutions. In other countries, property may be less important than quality and education services provided. The current situation in Brazil, where all public higher education is free, and all private education is fully charged to the students, is unwarranted in face of the similarities of the two systems, and should the adjusted, based on considerations of social benefits and equity. Subsidies should go to the most deserving students and best study programs, regardless of their institutional location. Because of their long-term private benefits, students should be asked to share the costs of their higher education, with appropriate study loans for those who need it. Public expenditures in higher education should be balanced with the priority to improve public support to good quality basic education.

Quality enhancement and control are central concerns. Since all higher education institutions provide degrees with the same legal validity, the assumption is that all degrees are equivalent in terms of content. It practice, they may be very different, and there is no simple way to enforce standards. Differentiation can mean not only variations in quality, but different goals and conceptions about what the student should or could learn. There is a constant struggle, in Brazilian higher education, between demands for more vacancies and less regulation, coming from prospective students and education providers in the private sector, and demands for more regulation and limitations to the opening of new courses and institutions, coming from professional associations, particularly in law and medicine, and from sectors in the civil service, as well as in the public universities. The National Assessment of Courses, in spite of known limitations, has created a "market for quality" that can help the public to maker better choices, and lead institutions to improve their standards. In addition to regular and public assess- 
ments, the dissociation between academic degrees and professional accreditation could go a long way in making higher education more flexible and pluralistic, while keeping standards in areas when it really matters.

Post-graduate education and university research are important assets, which should be supported and improved. However, mass higher education systems require different institutions, some more oriented towards research and graduate education, others more oriented to teaching, or professional education. The notion that all higher education institutions should do research, and that all post-graduate students should get free education and fellowships, leads to growing costs, unwarranted subsidies, and limited results. Research and advanced post-graduate education should be supported according to strict criteria of quality and relevance, and this support needs to be substantial and sustained. Students doing post-graduate work in order to enhance their future career opportunities and revenues should be asked to share the costs of their education.

Any compensatory policy in higher education should be balanced with the observation that the most important problems of inequity are in basic education, where a large proportion of students never complete their degrees, and remain functionally illiterate (OECD 2001, 2003). Once the student has a secondary degree, it is not difficult to enter higher education, although not necessarily in the field and institution of his choice. As secondary education expands, the demand for higher education will also increase, and it is necessary to develop policies to make sure that the best education does not remain restricted to students coming from high income, high education families and the richer regions, as it happens predominantly today. Subsidies, loans, quotas, lax admission policies and regional redistribution of resources will not be sufficient achieve this objective. To broaden the social basis, it is necessary to develop appropriate study programs for students coming from lower socioeconomic backgrounds, in- cluding a significant expansion of shorter, vocationally oriented post-secondary education, which is still very limited in Brazil.

Proper policies for higher education should deal with the issues of equity, quality and relevance, and combine them with other considerations, related to changes in the regulatory framework, quality assessment, the reorganization of public institutions, and improved efficiency and efficacy in the use of public resources.

\section{RESUMO}

A educação superior brasileira duplicou de tamanho na década de 90 , passando de 1.5 para mais de três milhões de estudantes no período. Esta expansão ocorreu sobretudo pelo crescimento do setor privado, que, em 2002 , respondia a $70 \%$ das matrículas. Será que esta expansão está tornando a educação superior brasileira mais acessível a pessoas oriundas dos segmentos mais pobres da sociedade? Será que a qualidade da educação superior está caindo, por causa da velocidade desta expansão? Será que o Brasil está formando pessoas com as qualificações e em número adequado para permitir que o país participe da nova economia, globalizada e baseada no uso intensivo de conhecimentos? Que políticas devem ser implementadas, para maximizar os valores da equidade e da relevância social? Este artigo examina a evidência disponível, e sugere algumas respostas para estas questões.

Palavras-chave: educação superior, capital humano, equidade, mercado de trabalho, política educacional.

\section{REFERENCES}

BALBACHEVSKY E. Brazilian post-graduate education: emerging challenges to a successful policy. In: Schwartzman S and Brock C. (Ed.). The Challenges of Education in Brazil. Oxford, UK: Triangle Journals, Ltd. (Oxford Studies in Comparative Education). 2004.

Becker GS. 1964. Human Capital. New York: Columbia University Press.

BRUNNER JJ AND ElacQua G. 2003. Informe sobre capital humano en Chile. Santiago: Universidad Adolfo Ibañez. 
CAPES. 2003. Estatística da Pós-Graduação: Ministério da Educação, Coordenação de Aperfeiçoamento de Pessoal de Nível Superior.

Castro CDM and Levy DC. 2000. Myth, reality, and reform: higher education policy in Latin America. Washington, DC: John Hopkins University Press for the IDB. 112 p.

Collins R. 1979. The Credential Society. New York: Academic Press.

Collins R. 2000. Comparative historical patterns of education. In: Hallinan M. (Ed.). Handbook of The Sociology of Education. New York: Kluwer Academic; Plenum Publishers, Comparative historical patterns of education.

Comissão Especial da Avaliação da Educação SuPERIOR. 2003. Sistema Nacional de Avaliação da Educação Superior SINAES: Bases para uma nova proposta de avaliação da educação superior. Brasília: Ministério da Educação; Instituto Nacional de Estudos e Pesquisas Educacionais; Secretaria de Ensino Superior http://www.funadesp.org.br/downloads/ Nova_Proposta.pdf

De Ferranti DM, Perry G, Gill IS, Guasch JL, Manoney WF, Sánchez-PÁRamo C And Schady N. 2003. Closing the gap in education and technology. Washington, D.C.: World Bank. xii, 216 p. (World Bank Latin American and Caribbean studies).

Elias P and Purcell K. 2003. Researching Graduate Careers Seven Years On. Research paper. Warwick, UK: A research project jointly funded by the Economic and Social Research Council and the Higher Education Careers Services Unit. http://www2.warwick.ac.uk/fac/soc/ier/research/ glmf/researchpaper1.pdf.

FRY P. 2002. Politics, nationality and the meanings of "race" in Brazil. Daedalus (Proceedings of the American Academy of Arts and Sciences), 129(2): 83-118.

Fulton O, Gordon A and Williams G. 1982. Higher education and manpower planning a comparative study of planned and market economies. Geneva: International Labour Office. 127 pp.

Governo do Estado do Rio de Janeiro. 2000. Lei no 3524 .

IBGE. 1993. Pesquisa Nacional por Amostra de Domicílios (National Household Sample Survey) - PNAD
1992: Ministério do Planejamento, Orçamento e Gestão, Instituto Brasileiro de Geografia e Estatística.

IBGE. 2002. Pesquisa Nacional por Amostra de Domicílios (National Household Sample Survey) - PNAD 2001: Ministério do Planejamento, Orçamento e Gestão, Instituto Brasileiro de Geografia e Estatística.

IBGE. 2003. Pesquisa Nacional por Amostra de Domicílios (National Household Sample Survey) - PNAD 2002: Ministério do Planejamento, Orçamento e Gestão, Instituto Brasileiro de Geografia e Estatística.

INEP. 2002. Censo do Ensino Superior: Ministério da Educação, Instituto Nacional de Estudos e Pesquisas Educacionais. November 2003. http://www.inep.gov.br/superior/censosuperior/.

Leal CIS AND Werlang SRDC. 1990. Retornos em Educação no Brasil 1976-1986. Fundação Getúlio Vargas. Rio de Janeiro.

Ministério de Ciência e Tecnologia. 1999. Indicadores de ciência e tecnologia, esforços em ciência e tecnologia (C\&T) e dispêndios em pesquisa e desenvolvimento (P\&D) - dados preliminares, 1999. 2003. http://www.mct.gov.br/estat/ascavpp/ portugues/2_Recursos_Aplicados/ tabelas/tab2_5_1.htm.

OECD. 1999. Classifying educational programmes. Manual for ISCED-97 Implementation in OECD countries: Organization for Economic Cooperation and Development. http://www.staffs.ac.uk/ schools/graduate_school/access/docs/ OECD-education-classifications.pdf.

OECD. 2001. Knowledge and skills for life - first results from PISA 2000 - Education and skills. Paris: OECD Programme for International Student Assessment.http://www.pisa.oecd.org/knowledge/ home/intro.htm.

OECD. 2003. Knowledge and skills for life - further results from PISA 2000. Paris: OECD Programme for International Student Assessment. http://www.pisa.oecd.org/literacy/download.htm.

PresidênCIA DA RepúbliCA. 2001. Plano Nacional de Educação. Diário Oficial da União, n.October 1, 2001. http://prolei.cibec.inep.gov.br/prolei/ LoadAplication.asp?aplic=DetalhesNorma\&estilo $=$ BROWSERSEMGIF\&GetDetalhesInfoWeb. IdInformacao $=4176$. 
Psacharopoulos G AND Patrinos HA. 2002. Returns to investment in education: a further update. World Bank Policy Research Working Paper. Washington, D.C.: The World Bank. 2881.

http://econ.world-bank.org/files/ 18081_wps2881.pdf.

Sáinz PG AND La Fuente RM. 2001. Economic Growth, employment and income in Latin America a long term perspective. In: UNESCO-OREALC (Ed.). Analysis of Prospects of the Education in Latin America and the Caribbean. Santiago: Oficina Regional de Educación de la UNESCO para América Latina y el Caribe, Economic Growth, employment and income in Latin America a long term perspective, p. $88-108$.

Schultz TP. 1994. Human capital and economic development. Discussion paper: Yale University Economic Growth Center.

Schwartzman S. 2002a. Higher education and the demands of the new economy in Latin America. Background paper for the LAC Flagship Report. The World Bank. Washington, DC.

http://www.schwartzman.org.br/simon/flagship.pdf.

Schwartzman S. 2002b. A pesquisa científica e o interesse público. Revista Brasileira de Inovação 1: 361-395. http://www.schwartzman.org.br/simon/ pesquisa_cientifica_interesse_publico.pdf.

Schwartzman S. 2003. The Challenges of Education in Brazil. Oxford: Oxford University, Centre for Brazilian Studies. http://www.brazil.ox.ac.uk/ Schwartzman38.pdf.
Schwartzman J And Schwartzman S. 2002. O ensino superior privado como setor econômico. Ensaio - Avaliação e Políticas Públicas em Educação v.10, n.37, out-dez, p. 411-440.

http://www.schwartzman.org.br/simon/suppriv.pdf.

Serageldin I and Li B. 1983. Tools for manpower planning the World Bank models. World Bank staff working papers. TW Bank. Washington, DC: World Bank.

Stern S, Porter ME and Furman JL. 2000. The determinants of national innovative capacity. Washington: National Bureau of Economic Research (Working Paper Series).

Telles EE. 2003. Racismo à brasileira. Rio de Janeiro: Relume Dumará.

Ueda EM And Hoffmann R. 2002. Estimando o retorno da educação no Brasil. Economia Aplicada 6: 209238.

Universidade do Estado da Bahia. 2002. Resolução 196/202. Salvador, BA. http://www.uneb.br/ consu_consepe/Res.consu.quotas $\% 20$ para\%20afro-descendentes.pdf.

Velloso J and Balbachevsky E. 2002. Graduate Training and employment in Brazil. International Higher Education 29: 19-20.

Wolf A. 2002. Does education matter? myths about education and economic growth. London: Penguin. xiv, 332 p. 